\title{
Perceived seriousness of academic cheating behaviors among undergraduate students: an Ethiopian experience
}

\author{
Wondifraw D. Chala(i)
}

\author{
Correspondence: wondideg@gmail. \\ com \\ College of Social Science and \\ Humanities, Department of \\ Education, Dire Dawa University, \\ Dire Dawa, Ethiopia
}

\begin{abstract}
The study was conducted to examine perceived seriousness of academic cheating behaviors among undergraduate students in an Ethiopian University. A total of 245 (146 males and 99 females) regular undergraduate students were randomly selected from three colleges: business and economics, natural and computational science, and social science found in a university. Data were collected using a survey. The results indicated that majority of the respondents rated most cheating behaviors as "serious" The study found that although students perceived the seriousness of most cheating behaviors, they continued to actively engage in cheating. Furthermore, significant differences were found in the perception of the seriousness of academic cheating behaviors amongst students according to field of study and gender. Therefore, as today's undergraduate students are the employees of tomorrow and that the ethics they adopt and adhere to shape their behavior in the future, it is suggested that there is a need to make known to students the reality of academic integrity and to expose them to the consequences of violating students' academic code of ethics.
\end{abstract}

Keywords: Academic dishonesty, Cheating behavior, Gender, Field of study, Ethiopia, Higher education

\section{Introduction}

In many social and economic contexts individuals often face the choice to adopt different types of opportunistic or even illicit behavior to increase their welfare taking advantage of others for personal interests. It is common to see people cheating on taxes, free riding on public goods, claiming benefits without entitlement, bribing and corrupting public officials. Likewise, academic dishonesty is among these fraudulent behavior which is becoming a major concern and threat to education systems of almost all countries of the world.

Academic cheating as defined by Davis et al. (2009) is deceiving or depriving by trickery, defrauding, misleading or fooling another. They further explained that academic cheating/academic misconduct refers to acts committed by students that

(c) The Author(s). 2021 Open Access This article is licensed under a Creative Commons Attribution 4.0 International License, which permits use, sharing, adaptation, distribution and reproduction in any medium or format, as long as you give appropriate credit to the original author(s) and the source, provide a link to the Creative Commons licence, and indicate if changes were made. The images or other third party material in this article are included in the article's Creative Commons licence, unless indicated otherwise in a credit line to the material. If material is not included in the article's Creative Commons licence and your intended use is not permitted by statutory regulation or exceeds the permitted use, you will need to obtain permission directly from the copyright holder. To view a copy of this licence, visit http://creativecommons.org/licenses/by/4.0/. The Creative Commons Public Domain Dedication waiver (http://creativecommons.org/publicdomain/zero/1.0/) applies to the data made available in this article, unless otherwise stated in a credit line to the data. 
deceive, mislead, or fool the teacher into thinking that the academic work submitted by the student was a student's own work. Rana and Ajmal (2013) also defined it as "students attempt to present others' academic work as their own." It includes many activities such as cheating (seeking help from peers) on examination, copying other student's assignment, collaborating with others on individual assignments and using unauthorized material during examination. In the same vein, Anderman et al. (2009) has described academic cheating behaviors as four categories: information transfer between individuals, the use of assisting tools, exploitation of weakness, and copying answers or information. Commonly, cheating behavior is conducted in two activities, which are during tests/exams and homework. In addition, Cizek (2012) defined cheating as involving three domains: cheating by giving, taking, or receiving information from other during exam/test; cheating by using prohibited materials or information; and cheating to evade the assessment process.

Academic cheating is not a new phenomenon. The Chinese have been concerned about cheating for longer than most civilizations have been in existence. As explained by Bouville (2010), Over 2000 years ago, prospective Chinese civil servants were given entrance exams in individual cubicles to prevent cheating, and searched as they entered the cubicles for crib notes. The penalty for being caught at cheating in ancient China was not a failing grade or expulsion, but death, which was applicable to both the examinees and examiners. Since then, academic cheating has been a problem and continues to concern the educational communities. Studies have shown that academic cheating has become increasingly prevalent (Antneh and Asres 2014; Barabanell et al. 2018; Dyer et al. 2020; Jennifer et al., 2009 and Mebratu 2016) and is becoming a habit for a growing number of students (Bacon et al. 2019; Löfström and Kupila 2013; Miller et al. 2015; Quaraishi and Aziz 2017; Rana and Ajmal 2013; Davis et al. 2009; and Thomas et al., 2010). In the past 50 years, the number of students that self-report consistent or frequent cheating increased rather sharply, especially in regard to cheating on tests (Bertram Gallant 2020; McCabe et al. 2012; Parnther 2020). For instance, in the early 1960's, according to McCabe et al. (2001), cheating prevalence has been around 17\% while in the 1990's that number had increased to 38\%. Similarly, Hamlin et al. (2013) and Kü üktepe (2014) have reported cheating prevalence within the range of 50-70\%. Moreover, Burton et al. (2011) and Simkin and McLeod (2010) have estimated that between $60 \%$ - $95 \%$ of undergraduate students employed dishonest tactics at some point in their university career.

Investigating higher education institution students' perceptions of cheating is of particular importance because the implications of academic dishonesty are numerous-it affects the integrity of the learning process (Paris and Robert 2007; Davis et al. 2009), an individual's long-term behavior (Lupton and Chaqman 2002) and the ability of academic institutions to achieve their stated objectives (Rana and Ajmal 2013). For example, students who engaged in cheating are more likely to develop attitudes and habits that can interfere with their learning and this may ultimately lead to practicing graduates who are insufficiently prepared. Furthermore, acts of academic dishonesty undermine the assessment of student learning and interfere with the efforts of faculty to properly diagnose and address shortcomings in student learning (Jan et al. 2002; Lupton and Chaqman 2002; and Davis et al. 2009). 
Academic cheating in higher education institutions is universally considered as a serious problem. However, most studies on the subject were undertaken in western countries (Yazici et al. 2011 and Lim \& See, 2001) and focused on the prevalence, determinants, and different definition of cheating (Jan et al. 2002; Fienberg 2009; and Witherspoon et al. 2012). Only a handful of studies have explored how people perceive cheating behaviors (Fienberg 2009). Students' perception regarding the severity of cheating behavior affects both the frequency and likelihood of the activity i.e. cheating behavior. For example, if a student believes that copying from friends on exam is trivial cheating, greater frequency of this activity would be reported. A student who does not perceive certain cheating behaviors as being unethical is more likely to cheat (Elias and Farag 2010).

It is obvious that differences in socio cultural settings, demographic composition and even educational policies and programs bring about difference in students' perception of cheating behavior. For example, cross cultural studies conducted to examine students' attitudes toward academic cheating have found evidence that students of different nationalities and of different cultures vary significantly in their perceptions of academic cheating (Godfrey et al. 1993; Jan et al. 2002; and Fienberg 2009).

Similarly, Diekhoff et al. (1999) found that Japanese college students, as compared to US students, report higher levels of cheating tendencies, have a greater propensity to neutralize the severity of cheating behavior and are not as disturbed when observing someone cheating in class. Moreover, a comparative study conducted by Lupton et al. (2000) found significantly different levels of cheating between Polish and US business students. The Polish students reported much higher frequencies of cheating than their American counterparts and were more likely to feel it was not so bad to cheat on one exam or tell someone in a later section about an exam.

Although these few studies conducted in other countries have shed some light on the cultural and national aspect of the issues, the researcher believed that there is a need for further studies within different contexts in order to widen the empirical base of cheating studies and improve our understanding of students' perception of cheating behavior. Furthermore, research examining cheating in general and students' perception of cheating in particular in Ethiopian higher education institutions is scant. Few studies conducted so far in Ethiopian higher education institution focused on prevention and detection (Mengistu, 2019; Wubalem et al. 2020), faculty perception (Tefera and Kinde, 2009), nature and causes (Mebratu 2016), and consequences (Nelson, Devardhi, and Dino; Solomon 2017). These studies have shown that academic dishonesty is a serious problem and widely spread among university students in Ethiopia with the prevalence rate of ranging from $53 \%-96 \%$. In addition, the studies have suggested that much has to be done under the theme of academic dishonesty in Universities of Ethiopia. Therefore, this study was conducted to examine students' perception of cheating behavior in Dire Dawa University. The following research questions were raised.

- How do university students perceive seriousness of academic cheating behaviors?

- Do students perceive seriousness of academic cheating behaviors differently according to their demographic background?

- What is the prevalence rate of academic dishonesty among Dire Dawa university undergraduate students? 


\section{Conceptual framework}

Academic dishonesty is 'any fraudulent actions or attempts by a student to use unauthorized or unacceptable means in any academic work (Theart and Smit 2012). Jensen et al. (2001) also defines academic dishonesty as students' attempt to present others' academic work as their own. Academic cheating has two forms, which is cheating behavior such as copying answers of others and plagiarizing behavior such as citing without including the correct source. According to Craig and Dalton (2013), plagiarism includes intentional and unintentional actions in utilizing another person's work wrongly. It is conducted in the form of replicating another person's work, copying the whole text, or even buying another person's writing and then admitting it as one's own. It also refers an inaccurate and non-thorough behavior in quoting, citing, and reporting the source being used dishonestly (Spielberberger 2004).

On the other hand, cheating, as defined by Salkind (2008), a dishonest action with the element of deceiving with the goal of obtaining benefits or superiority from other students. Anderman et al. (2009) described cheating as four categories: information transfer between individuals, the use of assisting tools, exploitation of weakness, and copying answers or information. Cizek (2012) has defined academic cheating as any action taken before, during, or after the administration of a test and assignments that is intended to gain an unfair advantage or produce inaccurate results. Cizek (2012) further elaborated cheating as involving three domains: cheating by giving, taking, or receiving information from other during exam/test; cheating by using prohibited materials or information; and cheating to evade the assessment process. According to Davis et al. (2009) and Lambert et al. (2003), cheating includes, but is not limited to: lying; copying from another's test or examination; discussion at any time of questions or answers on an examination or test, unless such discussion is specifically authorized by the instructor; taking or receiving copies of an exam without the permission of the instructor; using or displaying notes, "cheat sheets," or other information devices inappropriate to the prescribed test conditions. For the purpose of this study, the author has used Anderman et al. (2009) and Cizek (2012) definition and/or description of academic cheating as they are detail and best describe the nature of academic cheating common among Ethiopian students at all levels.

Academic dishonesty is not a new phenomenon, indeed it has been extensively studied in the academic context and empirical evidence indicates that it is changing and increasing in recent years (Davis et al. 2009; Yardley et al. 2009; Jensen et al. 2001; McCabe et al. 2001). Results regarding the influence of gender on cheating behavior have been mixed (Godfrey et al. 1993; Davis et al. 2009). Evidence for the gender differences in cheating vary with some studies showing strong differences and others showing no differences between males and females. A good number of studies (e.g. Kobayashi and Tedor 2012; Lupton and Chaqman 2002; Peled et al. 2013) have reported that academic cheating is more frequent in boys than in girls. On the other hand, Trost (2009) found no difference between male and female. Some other study by Jacobson and his colleagues as cited in Jensen et al. (2001), in contrary, reported that females are more likely to cheat than males.

Furthermore, other studies have demonstrated that females tend to rate most academic cheating behaviors as "most serious" and unethical than males (Fienberg 2009; Whitley 2001; and Whitley et al. 1999). However, despite their negative attitudes 
towards cheating behaviors, females were found to be engaged in cheating behavior just as frequently as males. A Meta analysis conducted by Whitley et al. (1999) and Fienberg (2009) reported that although women show a more ethical attitude toward cheating than men, "in practice, women were almost as likely to cheat as men". Wilkinson (2009) suggested that a significant element in the issue of academic cheating is the students' beliefs about right and wrong, and the level of seriousness attached to specific instances of wrong-doing. Moreover, McCabe and Trevino (1993) explained that as the perceived severity of punishments increases, the levels of individual cheating will become lower.

On the other hand, Elias and Farag (2010) contend that business students with a love of money do not perceive certain cheating behaviors as being unethical, and are therefore, more likely to cheat. Morris and Kilian (2006) confirm this argument with their study conducted in seven US universities. They have found that undergraduate accounting majors and business major students report higher frequencies of cheating than other major students. Therefore, Oneill and Pfeiffer (2012) concludes that if accounting students lack academic integrity, then accounting scandals are not surprising. They suggest appropriate training in ethics is necessary for business students.

Researchers have shown that dishonesty in college, cheating in particular, is a predictor of unethical behavior in subsequent professional settings (Lupton and Chaqman 2002 \& Lim and See 2001). In other words, people who engaged in dishonest behaviors during their college days continue to do so in their professional careers. Lupton and Chaqman reported that successful cheating behaviors in college carry over as a way of life after college. The works of Sims (1993) also confirmed this fact. Sim has found that people who engaged in dishonest behaviors during college are more likely to commit dishonest acts of greater severity at work.

The literature on students' perception of academic dishonesty include aspects such as what constitute cheating, seriousness of cheating behavior, why and how cheating occurs, and how cheating can be discouraged. This study, however, is delimited to the study of undergraduate students' perception about the seriousness of academic cheating behaviors among undergraduate students. Moreover, of the three types of academic dishonesty, i.e. exam-related, assignment-related, and research-related, usually mentioned in different literatures, exam and assignment related academic dishonesty were considered in this study.

\section{Methods and materials}

This study used descriptive survey research method. A total of 245 (146 males and 99 females) senior undergraduate students were selected from three colleges (Social Science and Humanities, Business and Economics, and Natural and Computational Sciences) found within a University at Dire Dawa City, Ethiopia, using stratified and simple random sampling. In the selection of participants, they were told that their participation is voluntary and the result will be reported in aggregate. To measure students' perception about the seriousness of academic cheating behavior, the researcher adopted academic dishonesty questionnaire used by Oneill and Pfeiffer (2012) and Witherspoon et al. (2012). Eleven items that fit to the context of Ethiopian Universities were selected from the instruments. In other words, academic cheating behaviors that are common and in Ethiopian universities are 
considered. For instance, cheating using internet is currently impossible because of no access to internet in examination rooms. Few of the items were modified based on the review of literature and experience of the researcher as University instructor. All the items are considered as academic cheating.

In the questionnaire, students were asked to indicate how often they had undertaken a particular cheating behavior (rated in three scale i.e. $0=$ never, $1=$ once, 2 more than once) and the degree to which they perceived the seriousness of the cheating behavior (rated in five scale i.e. $0=$ not at all cheating, $1=$ trivial cheating, $2=$ moderate cheating, $3=$ serious cheating and $4=$ most serious cheating). The lower the value of the perception shows that the students accept the behavior as normal (acceptable).

Pilot testing was made to test and fit the instrument with the context of Universities in Ethiopia. Forty (40) students from the institute of technology participated in the pilot test and the Cronbach alpha coefficients of all the items included in the main study were acceptable with the coefficient values of 0.80 and above. Finally, as gaining accurate data on cheating is difficult, the researcher went to some effort to make sure that the students answered frankly and honestly. The students were informed at the beginning of the data collection sessions about purpose of the study and anonymity of their responses. In the actual data collection, the questionnaires were administered while students were in classroom, before the beginning of new session.

\section{Results}

The purpose of the study was to assess perceived seriousness of academic cheating behaviors among undergraduate students. Depending on the nature of the data, quantitative data analysis techniques such as frequency, percentage, mean, independent t-test, one-way ANOVA, and chi-square were employed. Table 1 presents the perceived seriousness of academic cheating behaviors as rated by the respondents.

Table 1 summarizes the mean perceived seriousness ratings for items pertaining to respondents' attitudes toward academic cheating behaviors. The findings indicate that respondents surveyed generally perceived cheating behaviors to be "serious" (with a

Table 1 Perceived seriousness of cheating behaviors as rated by students

\begin{tabular}{ll}
\hline Cheating behaviors & Mean $(\mathbf{N}=\mathbf{2 4 5})$ \\
\hline 1. Doing less than your fair share of work on a group project. & $3.46(.70)$ \\
2. Copying from a nearby student during a quiz, test, or exam. & $3.22(.75)$ \\
3. Using text messaging to get/send answers on test. & $3.40(.69)$ \\
4. Allowing someone to copy your answers during a test or examination. & $\mathbf{1 . 6 9}(.69)$ \\
5. Taking crib notes (unauthorized by a teacher) to an exam/test halls. & $3.39(.72)$ \\
6. Working on an assignment in group when individual work is assigned. & $3.04(.88)$ \\
7. Writing on the hands, chairs, walls of exam halls etc. & $3.07(.84)$ \\
8. Doing other students' coursework/assignment for them. & $\mathbf{1 . 8 8}(.77)$ \\
9. Copying homework from another student. & $3.28(.72)$ \\
10. Whispering the answers to friends during an examination. & $\mathbf{1 . 7 3 ( . 7 0 )}$ \\
11. Allowing own coursework/assignment to be copied by another student. & $3.46(.72)$ \\
Grand Mean & $\mathbf{2 . 8 7}(.74)$
\end{tabular}

Notes: 0 (not cheating at all) to 4 (most serious cheating) Standard deviations are in parenthesis 
mean of 2.87). Not all cheating behaviors were perceived to be equally serious. The findings show that allowing someone to copy one's answer during a test or examination; doing other students' course work/assignment; and whispering the answers to friends during examination had mean scores below $2(\mathrm{M}=1.69, \mathrm{M}=1.88$, and $\mathrm{M}=1.73$ respectively) suggesting that these activities were considered only as moderate cheating by the respondents. Whereas cheating behaviors such as failure to contribute one's fair share in group project $(\mathrm{M}=3.46)$ and allowing own course work/assignment to be copied by another students $(M=3.46)$ were perceived as most serious academic misconduct.

An overall t-test comparison between male and females respondents indicated statistically significant difference in their perception of seriousness of academic cheating behaviors [ $\mathrm{t}(243)=10.08, p<.05]$ meaning female students perceive academic cheating behaviors as more serious $(\mathrm{M}=3.04, \mathrm{SD}=.21)$ than males $(\mathrm{M}=2.76, \mathrm{SD}=.22)$. More specifically, the result of the independent sample t-test, as can be seen from Table 2, indicated that there were statistically significant difference in the seriousness perception of item 1, 2, 3, 6, and 9 between male and female: "doing less than one's fair share in group project $[\mathrm{t}(243)=4.375, \mathrm{p}<05]$, such that female students perceive this behavior as more serious $(\mathrm{M}=3.71, \mathrm{SD}=.52)$ than male $(\mathrm{M}=3.29, \mathrm{SD}=.75)$; "copying from a nearby students during exam, test or quiz [ $\mathrm{t}(243)=7.221, \mathrm{p}<05]$, such that female students perceive this misconduct as more serious $(\mathrm{M}=3.59, \mathrm{SD}=.59)$ than males $(\mathrm{M}=$ $2.96, \mathrm{SD}=.73)$; "using text messages to get/send answers on test or exam" [t $(243)=$ 3.901, $p<05]$, such that female students perceive this misconduct as more serious $(\mathrm{M}=3.61, \mathrm{SD}=.53)$ than males $(\mathrm{M}=3.27, \mathrm{SD}=.75)$; "working on an assignment in group when individual work is assigned" [ $\mathrm{t}(243)=7.321 . p<05]$, such that female students perceive this misconduct as more serious $(\mathrm{M}=3.49, \mathrm{SD}=.68)$ than males $(\mathrm{M}=$ $2.73, \mathrm{SD}=.87)$; and "copying homework/assignment from another student" [ $\mathrm{t}(243)=$

Table 2 Gender difference in perceived seriousness of academic cheating behavior

\begin{tabular}{|c|c|c|c|c|c|c|}
\hline \multirow{3}{*}{ Items } & \multicolumn{2}{|l|}{ Gender } & \multicolumn{4}{|c|}{ Colleges } \\
\hline & \multirow{2}{*}{$\begin{array}{l}\text { Male } \\
\text { Mean }\end{array}$} & \multirow{2}{*}{$\begin{array}{l}\text { Female } \\
\text { Mean }\end{array}$} & \multirow[b]{2}{*}{$\mathbf{P}$} & \multirow[b]{2}{*}{ CBE } & \multirow[b]{2}{*}{ CNCS } & \multirow[b]{2}{*}{$\mathrm{CSSH}$} \\
\hline & & & & & & \\
\hline 1. Item 1 & $3.29(.75)$ & $3.71(.52)$ & .000 & & & \\
\hline 2. Item 2 & $2.96(.73)$ & $3.59(.59)$ & .000 & & & \\
\hline 3. Item 3 & $3.27(.75)$ & $3.61(.53)$ & .000 & & & \\
\hline 4. Item 4 & $1.65(.69)$ & $1.75(.69)$ & .283 & & & \\
\hline 5. Item 5 & $3.27(.77)$ & $3.56(.63)$ & .003 & & & \\
\hline 6. Item 6 & $2.73(.87)$ & 3.49 (.68) & .000 & & & \\
\hline 7. Item 7 & $3.01(.77)$ & $3.16(.92)$ & .175 & & & \\
\hline 8. Item 8 & 1.91 (.77) & $1.84(.77)$ & .472 & & & \\
\hline 9. Item 9 & $3.08(.71)$ & $3.57(.64)$ & .000 & & & \\
\hline 10. Item 10 & $1.76(.66)$ & $1.70(.76)$ & .489 & & & \\
\hline 11. Item 11 & $3.41(.68)$ & $3.52(.76)$ & .297 & & & \\
\hline Grand Mean & $2.76(.22)$ & $3.04(.21)$ & .000 & $2.79(.21)$ & $2.94(.27)$ & $2.91(.27$ \\
\hline
\end{tabular}

Notes: 0 (not cheating at all) to 4 (most serious cheating); CBE $(n=97)$, CNCS $(n=82)$, and CSSH ( $n=66)$ Standard deviations are in parenthesis. CBE College of Business and Economics, CSSH College of Social Science and Humanities, CNCS College of Natural and Computational Sciences. Items are numbered as the same as Table 1 
5.341, $p<05$ ], female students perceive this misconduct as more serious $(M=3.57$, $\mathrm{SD}=.64)$ than males $(\mathrm{M}=3.08, \mathrm{SD}=.71)$.

A one way analysis of variance (ANOVA) was conducted to compare mean score of students among the three colleges: Social Science, Business and Economics, and Natural and Computational Sciences. As can be understood from Table 3, there were statistically significant difference between the mean score of students' perceived seriousness of academic cheating behaviors among the colleges $(2,242)=7.754, p=001$ : the result of the tukey HSD indicate a statistically significant difference between college of Business and Economics and the other two colleges.

Table 4 above summarizes the percentages of respondents who admitted to having engaged on at least one occasion in each cheating activity surveyed. The majority of respondents $(81.26 \%)$ indicated that they had committed one of the surveyed cheating activities at least once; only $18.74 \%$ reported that they had never been involved in any form of cheating. This is an indication that cheating behavior was highly prevalent among the students participated in the study. This finding was congruent with the past study carried out in Addis Ababa and Jimma Universities by Tefera and Kinde (2009) who found that $82-96 \%$ of the students had committed one form of cheating at least once.

Descriptive statistics depicted in Table 4 suggest that a high percentage of respondents (about 93\%) reported having allowed others to copy their answers during test or examination. Approximately 93\% admitted that they have done an assignment/coursework for other students. Again more than $91 \%$ of the respondent reported that they have whispered answers to their friends during examination at least once. These findings might not be surprising as these behaviors rated as moderate cheating activities by the students (Table 1). Using text message to get/send answers in examinations recorded the lowest frequency at $16.33 \%$. The study also examined whether there is an association between variables like gender and field of study (stream) and cheating behavior. To do this, a chi square test was applied and the results are indicated in the following tables Table 5 .

Regarding gender difference in prevalence of cheating, the study revealed no difference between males and females. Approximately $81 \%$ of male respondents reported having cheated at least once. Similarly $80 \%$ of female respondents admitted that they have engaged in one of the cheating behavior at least once. The chi-square test is found to be not significant at $\mathrm{x}^{2}=0.222, \mathrm{df}=1, p>0.05$. This shows that although females perceived academic cheating behaviors more serious than their counterpart, the engaged in those activities as equal as males Table 6.

As can be seen from Table 6 above, the results of the chi square test demonstrated that there is a significant difference among colleges in self-reported cheating behavior.

Table 3 ANOVA result regarding respondents' perception of seriousness of cheating behavior among the three schools

\begin{tabular}{lllcll}
\hline Perception & Sum of squares & df & Mean square & F & Sig. \\
\hline Between groups & .966 & 2 & .483 & 7.754 & .001 \\
Within groups & 15.077 & 242 & .062 & & \\
Total & 16.043 & 244 & & & \\
\hline
\end{tabular}

Note: the mean difference is significant at the .05 level 
Table 4 Prevalence of cheating

\begin{tabular}{ll}
\hline Cheating behaviors & Cheated at least once (\% \\
\hline 1. Doing less than your fair share of work on a group project. & 83.27 \\
2. Copying from a nearby student during a quiz, test, or exam. & 88.98 \\
3. Using text messaging to get/send answers on test. & 16.33 \\
4. Allowing someone to copy your answers during a test or examination. & $\mathbf{9 3 . 0 6}$ \\
5. Taking crib notes (unauthorized by a teacher) to an exam/test halls. & 86.94 \\
6. Working on an assignment in group when individual work is assigned. & 86.12 \\
7. Writing on the hands, chairs, walls of exam halls etc. & 88.98 \\
8. Doing other students' coursework/assignment for them. & $\mathbf{9 3 . 4 7}$ \\
9. Copying homework from another student. & 84.49 \\
10. Whispering the answers to friends during an examination. & $\mathbf{9 1 . 0 2}$ \\
11. Allowing own coursework/assignment to be copied by another student. & 81.22 \\
Average & $\mathbf{8 1 . 2 6}$ \\
\hline
\end{tabular}

The chi square test among the three colleges were statistically significant at $x^{2}=6.530$, $\mathrm{df}=2, p<0.05$. To examine which college's students involve more in cheating behavior, further analysis of standardized residual test was computed. The result is indicated in Table 7 below.

As shown in Table 7, there is a significant difference between business and economics students and the remaining two colleges in cheating. This suggests that students of business and economics have engaged more in cheating behaviors than students of college of natural \& computational sciences and social science \& humanities. In other words, business and economics students engaged more in cheating behaviors than college of natural \& computational sciences and social science \& humanities.

\section{Discussion}

The study revealed that majority of the respondents perceived most cheating behaviors as serious problems. Respondents perceived cheating behaviors such as doing less than one' fair share in group assignment; using text messages to send/ receive answers; taking crib notes to the exam halls; and allowing own coursework/ assignment to be copied by others to be more serious. Such finding is congruent with previous researches (Yazici et al. 2011; Yardley et al. 2009; McCabe et al. 2001; Lim and See 2001; and Peled et al. 2013).

It is interesting that "cheating in the form of allowing someone to copy during exam"; "doing homework for others"; and "whispering the answers to friends during examination" were perceived by respondents to be least/moderate cheating and accordingly more incidence of these behaviors were reported. It is clear that cheating would be more likely to occur where students view cheating as a minor problem. This finding is congruent with the study of Oneill and Pfeiffer (2012) who found that allowing

Table 5 Gender difference in prevalence of cheating

\begin{tabular}{llllll}
\hline Gender & $\mathbf{O}$ & $\mathbf{E}$ & $\mathbf{X}^{\mathbf{2}}$ & $\mathbf{d f}$ & $\boldsymbol{P}$-value \\
\hline Male & 119 & 120.4 & $\mathbf{0 . 2 2 2}$ & 1 & $\mathbf{0 . 6 3 8}(>\mathbf{0 . 0 5})$ \\
Female & 83 & 81.6 & & & \\
\hline$p>0.05$ & & & & &
\end{tabular}


Table 6 Difference in prevalence of cheating among colleges

\begin{tabular}{llllll}
\hline Colleges & $\mathbf{O}$ & $\mathbf{E}$ & $\mathbf{X}^{\mathbf{2}}$ & $\mathbf{d f}$ & $\boldsymbol{P}$-value \\
\hline Business and economics & 86 & 78.4 & $\mathbf{6 . 5 3 0}$ & 2 & $\mathbf{0 . 0 3 8}(<0.05)$ \\
Natural \& comp. Sciences & 63 & 66.3 & & & \\
Social Science & 49 & 53.3 & & & \\
\hline$P<0.05$ & & & & &
\end{tabular}

$P<0.05$

someone to copy one's answers during a test or examination and whispering the answers to friends during an examination are considered as trivial cheating, accordingly, greater frequency of this activity was reported. Similarly, Graham (1994) reported that students with lenient attitudes towards academic cheating behaviors reported more cheating as compared to students with stricter attitudes. The reason why this happen might be beyond the scope of this study, however, one possible explanation according to McCabe (2005) is the probability of being caught and severity of the punishment for that specific behavior. Trost (2009), for example, contend that students believe that some academic cheating behaviors are more acceptable or tolerated than others because of the variations in disciplinary consequences of the academic dishonesty. In addition, Hutton (2006) found that students believed that engagement in academic cheating behaviors in school were alright because they saw the school doing nothing towards the behavior. Similarly, Oneill and Pfeiffer (2012) underlined that the probability of being caught and penalized are the most effective predictors of student engagement in academic cheating. The severity of punishment for cheating is the value which a student weighs the benefits he/she will gain from not being caught. To put it differently, some students may rationally assess the costs and benefits of their actions.

However, despite their perception, still majority (81\%) of the respondents reported that they have engaged in cheating behavior at least once. In other words, though the students perceive cheating as serious problem and unethical, they couldn't be deterred from cheating. This finding is in agreement with what Tefera and Kinde (2009) have reported. Cheating behaviors such as copying from a nearby student during a quiz, test, or exam; allowing someone to copy your answers during a test or examination; writing on the hands, chairs, walls of exam halls; doing other students' coursework/assignment for them; and whispering the answers to friends during an examination are the top five cheating behaviors with high rate of incidence. Wilkinson (2009) and Lupton and Chaqman (2002) also reported that copying from another student in an exam and/or assignment are forms of misconduct that have become areas of increasing concern for academics in higher education.

According to Wilkinson (2009) and McCabe et al. (2001), though majority of the students indicated academic cheating behaviors as unacceptable behavior, they do not condone cheating. Davis et al. (1992) also reported inconsistency between students' belief about the seriousness of academic cheating behaviors and their actual behavior.

Table 7 Standardized residual test of colleges in prevalence of cheating

\begin{tabular}{lllll}
\hline Colleges & O & E & O - E & R \\
\hline Business and economics & 86 & 78.4 & 7.6 & 0.9 \\
Natural \& comp. Sciences & 63 & 66.3 & -3.3 & -0.4 \\
Social Science & 49 & 53.3 & -4.3 & -0.6 \\
\hline
\end{tabular}


Davis and his colleagues found that around $90 \%$ of students affirmed that cheating is incorrect but $76 \%$ of them admitted they have cheated at least once. In this regard, as discussed above, the likelihood of getting caught, instructors' supervision, and the severity of the punishment matters a lot in students' behavior.

In addition, the study compared the ratings of female and male students to determine if there are gender differences in beliefs about seriousness of cheating behaviors. Accordingly, female students consistently rate the items as more serious than male students. In other words, females have shown more ethical attitudes towards most academic cheating behaviors than males. "Doing less than one's fair share of work on a group project; copying from a nearby student during a quiz, test, or exam; using text messaging to get/send answers on test; working on an assignment in group when individual work is assigned; and copying homework from another student are the activities where females showed more ethical attitude than their male counterpart. A metaanalysis conducted by Whitley et al. (1999) and Fienberg (2009) also affirmed this finding. The irony here is that however, females have perceived most cheating behavior as serious and inappropriate acts, the study revealed that they got engaged in cheating as frequently as males. This finding is against the findings of most previous researches who found that males are more likely to cheat than females (Kobayashi and Tedor 2012; Oneill and Pfeiffer 2012; and Peled et al. 2013). On the other hand, the finding is congruent with previous studies (e.g. Anitsal et al. 2009; Monahan et al. 2018; Quaraishi and Aziz 2017; Whitley et al. 1999; Fienberg 2009) who have reported no difference between males and females in cheating. Such inconsistency, thus, strengthen Klein et al.'s (2007) argument that explain gender as an inconsistent determinant of academic dishonesty.

The study also revealed that business and economics students have shown less ethical attitude towards academic dishonesty than students from the school of social science and humanities and school of natural and computational sciences. Moreover, the students of business and economics students have engaged in cheating more than students in the school of social science and humanities and natural and computational sciences. The same was found by Elias and Farag (2010). According to Elias and Farag, business students, with love of money, do not perceive certain cheating behaviors as unethical, and therefore, more likely to cheat than others. Another study by Morris and Kilian (2006) also found that undergraduate Accounting majors and business major students report higher frequencies of cheating than other major students. A recent study by Dyer et al. (2020) have also concluded that academic honesty runs particularly high among business students.

\section{Conclusion and implications}

This study presented some limitations. First, data are based on self-reports which would may result in the vulnerability to socially response bias because of the sensitive nature of the topic. This may have resulted in under-reporting of cheating during tests and examinations. The researcher attempted to avoid this problem by guaranteeing complete anonymity and emphasizing the importance of honest answers to the questions. Future investigations shall collect such data also from other sources (e.g., institutional reports related to honor code violations) and informants (e.g., course mates and teachers). Second, being conducted in a single University and the small sample may not 
be representative of University students in Ethiopia. Thus, findings of this study should be replicated on other Universities with large number of students and varied compositions for comprehensive understanding of academic cheating. Despite the limitation, however, this study has shed some light with regard to how university students perceived academic cheating behaviors in the Ethiopian context.

From the findings, it would be concluded that cheating is rampant in the university and students seems to be tolerant of unethical academic behaviors. This conveys a clear message that academic institutions has revisit their academic integrity policies and take necessary measures to deter academic cheating as its impact goes beyond the individual impact of crossing a moral or ethical boundary. Chace (2012) and Mensah et al. (2016) underlined that it reduces the perceived academic integrity of the institution, devaluing degrees earned from that institution. Similalry, Wollack and Cizek (2017) added that academic cheating threatens the validity of those credentials. Students who cheat rather than learn to pass courses are less prepared for the workforce and are more likely to engage in behaviors that are similarly unethical (Smyth et al. 2009; Teixeira and Rocha 2010). In view of this, the researcher discussed the implications as follows;

The researcher believes that high prevalence of the cheating as witnessed in the study might be attributed to the less probability of getting caught and severity or absence of punishment. Thus, the university has to revisit the strength and applications of its students' code of conduct. As argued by Vandehey et al. (2007), students' concern for being caught and punished for cheating was far more effective as a deterrent to academic misconduct than the student's internal feelings toward the act. Vandehey et al. (2007) further emphasized that student punishment factors continued to be the best deterrents to student academic misconduct. If students are caught cheating, accused, and have a severe admonishment, it is more likely that, according to Petress (2003), the behavior can be curtailed. Levy and Rakovski (2007) also added that students' engagement in academic dishonesty decreased when they knew the cheating would be discovered and severely punished.

Moreover, given the essential nature of academic integrity to the academic mission of an institution, preventing academic dishonesty on the most common form of assessment (testing) is of high value to many colleges and universities. In classrooms and in the test center environment, this threat to academic integrity should lead to very strict security rules. Students should be observed at all times while taking test and/or examination and invigilators must be able to intervene immediately if there is any unusual testing behavior.

Above all, following an educational approach would be noteworthy to bring about long-term and sustainable changes within the minds of our students. Accordingly, the integration of academic integrity into every curriculum would seem to provide a potential means of increasing students' ethical sensitivity and, hence, behavior. Emphasizing this, Nonis and Swift (2001) have stated that we can implement fundamental approach involving the teaching of integrity and discussion of ethical issues in every subject, with particular emphasis in the capstone subjects instead of integrating a stand-alone ethics education/subject. Such an approach, according to Nonis and Swift (2001), focuses not so much on teaching students the rules of ethical analysis, but on providing a strong ethical foundation that becomes deep-rooted within students' personality over the duration of 
their studies so that they come to value integrity and honesty in their own behavior. The last, but not the least, more researches on academic integrity at all levels of the education ladder shall be conducted so that timely and preventive alternatives shall be considered. Moreover, higher education institutions and/or other stakeholders of the education sector shall encourage such studies through funding and dissemination thereby maximizing quality education.

\section{Abbreviation}

ANOVA: Analysis of Variances; CBE: College of Business and Economics; CNCS: College of Natural and Computational Sciences; CSSH: College of Social Sciences and Humanities; HSD: Honestly significant difference

\section{Acknowledgments}

I would like to thank the students who voluntarily participated in this study. I want to extend my gratitude to Dire Dawa University, its academic staffs and college deans who allowed and helped me to collect the data.

\section{Author's contributions}

The sole author designed, analyzed and interpreted, and prepared the manuscript. The author(s) read and approved the final manuscript.

\section{Author's information}

Wondifraw Dejene Chala is an assistant professor in Curriculum and Instruction serving as a teacher-educator in DireDawa University, Dire Dawa, Ethiopia, since 2007. His research interests include, but are not limited to, initial teacher education, multicultural education, teacher beliefs, teacher-educators' classroom practice, inclusive education; academic integrity; and gender equality in education.

\section{Funding}

The author received no direct funding for this research.

\section{Availability of data and materials}

Raw data and materials are not attached because of the fact the nature the data (being on academic cheating) may spoil the images of the institutions and/or departments. However, on request, the author could provide the data to concerned bodies.

\section{Competing interests}

The author declare that they have no competing interests.

Received: 19 June 2020 Accepted: 29 December 2020

Published online: 21 January 2021

\section{References}

Anderman M, Cupp K, Lane D (2009) Impulsivity and academic cheating. J Exp Educ 78(1):135-150

Anitsal I, Anitsal M, Elmore R (2009) Academic dishonesty and intention to cheat: A model on active versus passive academic dishonesty as perceived by business students. Acad Educ Leadersh J 13(2):17-26

Antneh D, Asres B (2014) Cheating on examinations and its predictors among undergraduate students at. Hawassa Univ Coll Med Health Sci Med Educ 14(89):1-11

Bacon A, McDaid C, Williams N, Corr P (2019) What motivates academic dishonesty in students? A reinforcement sensitivity theory explanation. Br J Educ Psychol:1-15 https://doi.org/10.1111/bjep.12269

Barabanell C, Farenes M, Tramontano C, Fida R, Ghezzi V, Paciello M, Long P (2018) Machiavellian Ways to Academic Cheating: A Mediational and Interactional Model. Front Psychol 9:695 https://doi.org/10.3389/fpsyg.2018.00695

Bertram Gallant T (2020) Academic integrity and the student affairs professional. In: Hornak AM (ed) Ethical and Legal Issues in Student Affairs and Higher Education. Charles C Thomas Publisher, Springfield, pp 95-133

Bouville M (2010) Why is Cheating Wrong? Stud Philos Educ 29(1):67-76

Burton H, Talpade S, Haynes J (2011) Religiosity and test-taking ethics among business school students. J Acad Bus Ethics 4: $1-8$

Chace W (2012) A question of honor: Cheating on campus undermines the reputation of our universities and the value of their degrees. Now is the time for students themselves to stop it. Am Sch 81(2):20-32

Cizek J (2012) Ensuring the integrity of test scores: Shared responsibilities. Paper presented at the annual meeting of the American Educational Research Association. Vancouver, British Columbia

Craig R, Dalton D (2013) Understanding first year undergraduate student perceptions of copying and plagiarism: developing a platform for a culture of honest inquiry and the academic construction of knowledge. In: Plagiarism across Europe and Beyond-Conference Proceedings, pp 103-114 June 12-13, Brno, Czech Republic

Davis F, Drinan F, Gallant B (2009) Cheating in Schools: What We Know And What We Can Do. Wiley, London

Davis SF, Grover CA, Becker AH, McGregor LN (1992) Academic Dishonesty: Prevalence, Determinants, Techniques, and Punishments. Teach Psychol 19:16-20

Diekhoff GM, LaBeff EE, Shinohara K, Yasukawa H (1999) College cheating in Japan and the United States. Res High Educ 40(3):343-353

Dyer J, Pettyjohn H, Saladin S (2020) Academic Dishonesty and Testing: How Student Beliefs and Test Settings Impact Decisions to Cheat. J Natl Coll Test Assoc 4(1):1-30 
Elias R, Farag M (2010) The Relationship Between Accounting Students' Love of Money and their Ethical Perceptions. Manag Audit J 25(3):269-281

Fienberg J (2009) Perception of Cheaters: The Role of Past and Present Academic Achievement. Ethics Behav 19(4):310-322

Godfrey, R., Waugh, R., Evans, E., Craig, D. (1993). Measuring Student Perceptions about Cheating: A Cross Cultural Comparison. A paper presented at the Australian Association for Research in Education Annual Conference held in Fremantle, WA from November 22 to 25

Graham M (1994) Cheating at Small Colleges: An Examination of Student and Faculty Attitudes And Behaviors. J Coll Stud Dev 35(4):255-260

Hamlin A, Barczyk C, Powell G, Frost J (2013) A comparison of university efforts to contain academic dishonesty. J Legal Ethic Regul Issues 16(1):35-46

Hutton P (2006) Understanding student cheating and what educators can do about it. Coll Teach 54(1):171-176

Jan R, Victor M, Dmitri L, Alexei V (2002) Tolerance of Cheating: An Analysis across Countries. J Econ Educ 33(2):125-135

Jensen J, Arnett J, Feldman S, Cauffman E (2001) It's wrong, but everybody Does it: Academic Dishonesty among High School and College Students. Contemp Educ Psychol 27:209-228

Klein H, Levenburg N, McKendall M, Mothersell W (2007) Cheating during the college years: How do business school students compare? J Bus Ethics 72(2):197-206

Kobayashi E, Tedor M (2012) Gender, Social Bond, and Academic Cheating in Japan. Sociol Inq 82(2):282-304

Küçüktepe S (2014) College students' cheating behaviors. Soc Behav Pers 42:101-112

Lambert E, Hogan L, Barton M (2003) 'Collegiate Academic Dishonesty Revisited: What Have They Done, How Often Have They Done It, Who Does It, and Why Did They Do It? Electron J Sociol 7(4) retrieved from http:/www.sociology.org/ content/vol7.4/lambert_etal_html

Levy ES, Rakovski CC (2007) Academic Dishonesty: Perceptions of Business Students. Coll Stud J 7(3):466-481

Lim V, See S (2001) Attitudes toward, and Intentions to Report, Academic Cheating Among Students in Singapore. Ethics Behav 11(3):261-274

Löfström E, Kupila P (2013) The instructional challenges of student plagiarism. J Acad Ethics 11:231-242

Lupton A, Chaqman J (2002) Russian and American College Students' Attitudes, Perceptions and Tendencies Towards Cheating. Educ Res 44(1):17-27

Lupton RA, Chapman K, Weiss J (2000) American and Slovakian University Business Students' Attitudes, Perceptions And Tendencies Toward Academic Cheating. J Educ Bus 75(4):231-241

McCabe D, Trevino L, Butterfield K (2001) Cheating in Academic Institution: A decade of Research. Ethics Behav 11(3):219-232

McCabe DL (2005) It Takes a Village: Academic Dishonesty. Lib Educ 91(3):26-31

McCabe DL, Trevino LK (1993) Academic Dishonesty. J High Educ 64(5):522-538

McCabe L, Butterfield D, Trevino K (2012) Cheating in College: Why Students Do It and What Educators Can Do about It. Johns Hopkins University Press, Baltimore

Mebratu M (2016) The nature, causes and practices of academic dishonesty/cheating in higher education: The case of Hawassa University. J Educ Pract 7(19):14-20

Mengistu A (2019) Written exam cheating and prevention and detection: the case of DMU. J Educ Pract 10(7):60-70

Mensah C, Azila-Gbettor M, Appietu M (2016) Examination cheating attitudes and intentions of students in a Ghanaian polytechnic. J Teach Travel Tour 16(1):1-19

Miller B, Agnich L, Posick C, Gould L (2015) Cheating around the world: A cross-national analysis of principal reported cheating. J Crim Justice Educ 26(2):211-232

Monahan M, Shah A, Shah R (2018) A comparison of the prevalence of dishonest academic behaviors between USA and German students. J Ethical Legal Issues 11:1-18

Morris DE, Kilian CM (2006) Do Accounting Students Cheat? A Study Examining Undergraduate Accounting Students' Honesty and Perceptions of Dishonest Behavior. J Account Ethics Public Policy 5(3):375-393

Nonis S, Swift C (2001) An examination of the relationship between academic dishonesty and workplace dishonesty : A multi-campus investigation. J Educ Bus 77(2):69-77

Oneill H, Pfeiffer C (2012) The Impact of Honor Codes and Perceptions of Cheating on Academic Cheating Behaviors, especially for MBA Bound Undergraduates. Account Educ Int J 21(3):231-245

Paris S, Robert D (2007) Cheating in Middle School and High School. Educ Forum 71:104-116

Parnther C (2020) Academic misconduct in higher education: A comprehensive review. J High Educ Policy Leadersh Stud 1(1):25-45

Peled Y, Eshet Y, Grinautsky K (2013) Perceptions Regarding the Seriousness of Academic Dishonesty amongst Students - A comparison Between Face-to-Face and Online Courses

Petress C (2003) Academic dishonesty: A plague on our profession. Education 123(3):624-627

Quaraishi U, Aziz F (2017) Academic Dishonesty at the Higher Education Level in Punjab, Pakistan. J Res Reflect Educ 11(1): 68-85

Rana R, Ajmal W (2013) Ethical Perception of University Students: Study of Academic Dishonesty in Pakistan. Middle-East J Sci Res 13(1):55-63

Salkind J (ed) (2008) Encyclopedia of Educational Psychology. SAGE Publications, Inc, California

Simkin M, McLeod A (2010) Why do college students cheat? J Bus Ethics 94(3):441-453

Sims R (1993) The Relationship between Academic Dishonesty and Unethical Business Practices. J Educ Bus 68(4):207-211

Smyth L, Davis J, Kroncke C (2009) Student's perceptions of business ethics: Using cheating as a surrogate for business situations. J Educ Bus 84(4):229-239

Solomon F (2017) Academic dishonesty in Ethiopian higher education and its implication for corruption. Beijing Law Rev 8: $10-20$

Spielberberger C (ed) (2004) Encyclopedia of Applied Psychology. Elsevier Inc

Tefera T, Kinde G (2009) Faculties' Perception and Responses to Academic Dishonesty of Undergraduate Students in Education, Business and Economics. Ethiop J Sci Educ 4(2):57-82

Teixeira A, Rocha M (2010) Cheating by economics and business undergraduate students: An exploratory international assessment. High Educ 59(6):663-701 
Theart CJ, Smit I (2012) The Status of Academic Integrity Amongst Nursing Students at A Nursing Education Institution in the Western Cape. Curationis 35(1):1-8

Trost K (2009) Psst, have you ever cheated? A study of academic dishonesty in Sweden. Assess Eval High Educ 34(4):367-337 Vandehey M, Diekhoff G, LaBeff E (2007) College cheating: A twenty-year follow-up and the addition of an honor code. J Coll Stud Dev 48:468-480

Whitley E (2001) Gender Differences in Affective Responses to Having Cheated: The Mediating Role of Attitudes. Ethics Behav 11:249-259

Whitley E, Nelson F, Jones P (1999) Gender Differences in Cheating Attitudes and Classroom Cheating Behavior: A MetaAnalysis. Sex Roles 41(1):657-680

Wilkinson J (2009) Staff and Student Perceptions of Plagiarism and Cheating. Int J Teach Learn High Educ 20(2):98-105

Witherspoon M, Maldonado N, Lacey C (2012) Undergraduates and Academic Dishonesty. Int J Bus Soc Sci 3(1):76-86

Wollack J, Cizek G (2017) Security issues in professional certification/licensure testing. In: Davis-Becker S, Buckendahl C (eds) Testing in the professions: Credentialing policies and practice. Taylor \& Francis, pp 178-209

Wubalem G, Gizachew W, Mezgebu A, Zemenu A, Alemneh M (2020) Possible Reduction Mechanisms of Exam Cheating Practices for First Year Management Regular Students in Human Resource Management Course. Am J Educ Inf Technol 4(1):19-27 https://doi.org/10.11648/j.ajeit.20200401.13

Yardley J, Rodríguez M, Bates S, Nelson J (2009) True Confessions? Alumni's Retrospective Reports on Undergraduate Cheating Behaviors. Ethics Behav 19(1):1-14

Yazici A, Yazici S, Erdem M (2011) Faculty and Student Perceptions on College Cheating: Evidence from Turkey. Educ Stud $37(2): 221-231$

\section{Publisher's Note}

Springer Nature remains neutral with regard to jurisdictional claims in published maps and institutional affiliations.

\section{Ready to submit your research? Choose BMC and benefit from:}

- fast, convenient online submission

- thorough peer review by experienced researchers in your field

- rapid publication on acceptance

- support for research data, including large and complex data types

- gold Open Access which fosters wider collaboration and increased citations

- maximum visibility for your research: over $100 \mathrm{M}$ website views per year

At $\mathrm{BMC}$, research is always in progress. 